\title{
Total Kjeldahl-N, Nitrate-N, C/N Ratio and pH Improvements in Chimato Composts Using Tithonia Diversifolia
}

\author{
Angstone Noel J. Thembachako MLANGENI ${ }^{1}$, Samson SAJIDU ${ }^{2} \&$ Sosten Staphael CHIOTHA ${ }^{3}$ \\ ${ }^{1}$ Basics Programme, NR department, Natural Resources College (of Malawi), Malawi \\ ${ }^{2}$ Chemistry department, Chancellor College, University of Malawi, Malawi \\ ${ }^{3}$ Leadership for Environment and Development (LEAD), Chancellor College, University of Malawi, Malawi \\ Correspondence: Angstone Noel J Thembachako Mlangeni, Natural Resources College (of Malawi), Malawi. Tel: \\ 265-888-301-288. E-mail: anjtmlangeni@gmail.com
}

Received: May 25, 2013 Accepted: August 5, 2013 Online Published: September 15, 2013

doi:10.5539/jas.v5n10p1 URL: http://dx.doi.org/10.5539/jas.v5n10p1

\begin{abstract}
The study investigated improvements of composting blended feedstock of $T$. diversifolia and maize stalks on total Kjeldahl-N (TKN), nitrate-N, C/N ratios and $\mathrm{pH}$ of chimato Composts. In this study, T. diversifolia/maize stalks (Td: MS) ratios: 0:100, 25:80, 20:80, 40:60, 50:50, 60:40, 75:25, 80:20 and 100:0 (v/v) were prepared and then composted using chimato composting technology. The TKN and organic carbon, nitrate- $\mathrm{N}, \mathrm{C} / \mathrm{N}$ ratios and $\mathrm{pH}$ were determined using standard methods. Results showed significantly higher TKN and nitrate-N and lower final $\mathrm{C} / \mathrm{N}$ ratios in chimato composts produced using $T$. diversifolia blending ratios of above $40 \%$ than those below ( $0 \%$ $(\mathrm{p}<0.001, \alpha=0.01), 20 \%(\mathrm{p}<0.018, \alpha=0.05)$ and $25 \%(\mathrm{p}<0.028, \alpha=0.05))$. Empirical models of the form $\mathrm{Y}=\mathrm{mX}+\mathrm{C}$ (where $\mathrm{Y}=T$. diversifolia percentage and $\mathrm{X}=\mathrm{TKN}$ or Nitrate- $\mathrm{N}$ percentage) were developed indicating significant effect of $T$. diversifolia on TKN and nitrate-N on resultant chimato composts. Results also showed significant improvement in TKN and nitrate- $\mathrm{N}$ content and $\mathrm{C} / \mathrm{N}$ ratios in composts with blending ratios of Td:MS = 40:60, Td:MS $=50: 50$ and Td:MS $=60: 40(\mathrm{v} / \mathrm{v})$ hence judged optimal. The observed significance is attributed to optimal initial $\mathrm{C} / \mathrm{N}$ ratios, moisture and porosity of the composite ingredients that enhanced active and rapid microbial aerobic activities that limited nitrogen volatilization. Blending composition of greater than $60 \%$ of $T$. diversifolia yielded reduced quantities of TKN and nitrate-N besides possessing greater quantities of nitrogen rich ingredients. The observations suggest occurrence of significant nitrogen volatilization. Thus, optimal Td:MS blending composition in the range of 50:50 to $60: 40(\mathrm{v} / \mathrm{v})$ should be promoted as one strategy of improving quality of composts among smallholder farmers.
\end{abstract}

Keywords: $T$. diversifolia, chimato compost, TKN, Nitrate-N, C/N ratio, maize stalks

\section{Introduction}

Application of organic composts to improve soil fertility has recently received greater attention as a comeback soil enrichment technology in Sub Saharan Africa and other countries (Nalivata, 2007). In Malawi, smallholder farmers are encouraged to make chimato using mostly crop residues, such as maize stalks, and grass as feedstock (DARETS, 2012). Organic resource quality of the feedstock influences decomposition and nutrient release rates and patterns of the finished compost product. Thus, organic resource quality is a function of the nutrient concentration in finished compost product. Maize stocks and grass, which are commonly used in Malawi, are judged of poor quality mainly because they possess large $\mathrm{C} / \mathrm{N}$ ratios $(\mathrm{C} / \mathrm{N}>60: 1)$ which provides the feedstock with little nitrogen (ICRAF, 2012; Ngeze, 1993) and yield finished product with high C:N ratio (C:N>30:1) (WSU, 2012). In addition, chimato composts made using poor quality feedstock take long to mature or do not mature at all. Carbon compounds in immature composts continue to break down once incorporated into the soil and in the process, microorganisms draw on soil nitrogen and oxygen to assist in the decomposition process which leaves the root zone temporarily nitrogen poor- thereby inversely inducing $\mathrm{N}$-immobilization process (Joern et al., 2008; Njira et al., 2012; Tsutsuki, 2009; Tani, 2009). Therefore, sole application of chimato composts made using low quality organic resources may lead to $\mathrm{N}$-immobilization, which diminishes available nitrogen to plants crop plant for their growth. Nitrogen meant for the crops is tied up and application of such composts may not meet the plants' demand for $\mathrm{N}$, hence negatively affecting plant growth (Nalivata, 2007; Chang et al., 2009; Tani, 2009; Tsutsuki, 2009). In addition, high level of continued microbial activity in 
unfinished compost requires a large intake of oxygen, and the microbes may pull this from the surrounding soil (Tsutsuki, 2009; Joern et al., 2008), which essentially suffocates the plant roots. Compost that is not well-decomposed (immature compost) has high C:N ratio (C:N>30:1) (WSU, 2012; Ngeze, 1993; Agromisa, 1990).

Since the nutrient content of product compost partly varies with the quality of organic resource materials (feedstock) (Murugan \& Swarnam, 2013; Sanchez \& Demchak, 2009), high quality recipe of composite feedstock need to be determined to enable farmers mix or blend different plant materials of known initial nitrogen content as well as initial $\mathrm{C}: \mathrm{N}$ ratios to produce fully matured chimato composts that possesses enormous nitrogen and low optimum final $\mathrm{C}: \mathrm{N}$ ratio (Tsutsuki, 2009; WSU, 2010). The blending is expected to increase nitrogen content of the composite feedstock as well as that of the finished product especially because there is a positive agreement between initial nitrogen content and available N (Njira et al., 2012; Murugan \& Swarnam, 2013). Legume clovers which are high quality organic resource materials (with nitrogen of about $1.80-3.6 \%$ nitrogen) are suggested to be blended with maize stalks and grasses to improves initial $\mathrm{C} / \mathrm{N}$ ratio of the mixture by increasing nitrogen content in the composite ingredients (Nalivata, 2007). However, Leguminous clovers are usually in short supplies and farmers prefer using them as livestock feed or fodder compared to using them as ingredients of chimato compost, which limit making of nitrogen rich chimato compost (Jama et al., 2000; Wambui et al., 2006). Tithonia diversifolia (T. diversifolia) is identified alternative to leguminous clovers. It is of high quality, sustainable feedstock likely to improve total Kjeldahl nitrogen, TKN, nitrate- $\mathrm{N}$ and $\mathrm{C} / \mathrm{N}$ ratio of chimato compost. It also possess low amounts of lignin and phenols, low $\mathrm{C} / \mathrm{N}$ ratio $(\mathrm{C} / \mathrm{N} \leq 10: 1)$ (Kiptot, 2008; Olabode et al., 2007) and soft and un-waxed leaves which provide favourable conditions for fast decomposition of the plant matter (SAEM, 2008) and is also reported to possess enormous nitrogen which is easily released when the plant quickly decomposes (SAEM, 2008). Biomass bulk of composted $T$. diversifolia is reduced by more than two-thirds implying labour and expenses of carrying green raw T. diversifolia biomass to the field which are feared by most smallholder farmers (Eghball \& Power, 1999; Gachengo et al., 1999) could be reduced by approximately one-half.the reduction could make compost application more economical and viable for smallholder farmers. Thus, nutrient laded shrubs of $T$. diversifolia are likely to produce mature composts which could be pivotal in improving soil nitrogen, the most limiting nutrient for plant growth in most soils in Malawi (Olabode et al., 2007; Sanchez \& Demchak, 2004; Nalivata, 2007; Njira et al., 2012). Therefore, the study was conducted to investigate improvements of composting blended feedstock of T. diversifolia and maize stalks on total Kjeldahl-N (TKN), nitrate-N, $\mathrm{C} / \mathrm{N}$ ratios and $\mathrm{pH}$ of chimato composts as well as the effect of different blending ratios of $T$. diversifolia and maize stalks varied physco-chemical parameters of the fineshed composts.

\section{Materials and Methods}

\subsection{Study Site}

The study was carried out at Natural Resource College (NRC) farm in Lilongwe District. NRC $\left(130^{\circ} 85^{\prime} \mathrm{S} 330^{\circ}\right.$ $38^{\prime}$ E) lies on an altitude of $1146 \mathrm{~m}$ above sea level, has a mean annual temperature of $200 \mathrm{C}$, a mean annual relative humidity of $68 \%$ and receives an annual mean rainfall of $892 \mathrm{~mm}$ of which $85 \%$ falls between November and March (DARETS, 2002).

\subsection{Feedstock Preparation and Composting Treatments}

Tender and green T. diversifolia shrubs of about 8 weeks old were cut, collected and chopped into small pieces ranging from $5.0 \mathrm{~cm}$ to $10.0 \mathrm{~cm}$ and then homogeneously blended with maize stalks to desired ratios. Chopping was done to increase surface area onto which microbes would act and to enhance efficient diffusion of air throughout the entire pile and enhance faster decomposition. Nine composting treatments $\operatorname{Td} 0, \operatorname{Td} 20, \operatorname{Td} 25$, $\mathrm{Td} 40, \mathrm{Td} 50, \mathrm{Td} 60, \mathrm{Td} 75, \mathrm{Td} 80$, and $\mathrm{Td} 100$ with $T$. diversifolia and maize were conducted. These corresponded to T. diversifolia/maize (Td:MS) ratios of 0:100, 25:80, 20:80, 40:60, 50:50, 60:40, 75:25, 80:20 and 100:0 (v/v) respectively.. A standard methodology of constructing a chimato compost pile was followed in each case (MMFS, 2010).

\subsection{Determination of Initial C/N Ratio of Chimato Composts Pile}

The initial $\mathrm{C} / \mathrm{N}$ ratios of composite ingredients of composting treatment were determined from literature values of $\mathrm{C} / \mathrm{N}$ ratios of $T$. diversifolia and maize stalks using equation 1 and 2 of blended feedstock. Equation 2 took into account masses, moisture contents and $\mathrm{C} / \mathrm{N}$ ratios of both ingredients and was used to check or validate results of Equation 1 .

$$
\text { Initial } \mathrm{C}: \mathrm{N} \text { Ratio }=\frac{(\mathrm{Tdm}(\mathrm{kg}) * \mathrm{TdC}: \mathrm{N})+(\mathrm{MSm}(\mathrm{kg}) * \mathrm{MSC}: \mathrm{N})}{\mathrm{Tdm}(\mathrm{kg})+(\mathrm{MSm}(\mathrm{kg})}
$$




$$
\text { InitialC : N Ratio }=\frac{\left(\left[\% \mathrm{C}_{\mathrm{TD}} * \mathrm{Td}_{\mathrm{m}} *\left(1-\mathrm{MTD}_{\mathrm{TD}}\right)\right]+\left[\% \mathrm{CMS}_{\mathrm{MS}} * \mathrm{MS}_{\mathrm{m}} *(1-\mathrm{M} \mathrm{MS})\right]\right)}{\left(\left[\% \mathrm{~N}_{\mathrm{TD}} * \mathrm{Td}_{\mathrm{m}} *\left(1-\mathrm{MTD}_{\mathrm{TD}}\right)\right]+\left[\% \mathrm{~N}_{\mathrm{MS}} * \mathrm{MS}_{\mathrm{m}} *\left(1-\mathrm{MMS}_{\mathrm{M}}\right)\right]\right)}
$$

(where $\mathrm{C} / \mathrm{N}$ is carbon nitrogen ratio, $\mathrm{TDm}=$ mass of $T$. diversifolia in $\mathrm{kg}, \mathrm{TDCN}=\mathrm{C} / \mathrm{N}$ ratio of $T$. diversifolia (10:1), $\mathrm{MSm}=$ mass of maize stalks in $\mathrm{kg} . \mathrm{MSC} / \mathrm{N}=\mathrm{C} / \mathrm{N}$ ratio of maize stalk $(60: 1), \mathrm{MTD}=$ moisture content of $T$. diversifolia $60 \%, \mathrm{MMS}=$ moisture content)

\subsection{Analysis of Chimato Composts}

From each Chimato Composts treatment, adequate sample for TKN and organic carbon analysis, were collected, dried to stop further decomposition, weighed using analytical balance, and then ground. Non-compost particles were separated from compost and both were weighed, packed and labeled ready analysis. Fine particles were separated from the course compost materials and weighed again.

\subsubsection{Determination of TKN, Organic Carbon and Nitrate-N in Chimato Compost}

Nitrate-N was determined using a UV-Visible spectro-photometric method from APHA (1989). Specifically, a Jenway model No.: 6405 digital UV-spectrometer was used at wavelength of $410 \mathrm{~nm} .2 .0 \mathrm{~g}$ of each fine sample was tested for TKN and organic carbon using the Kjeldahl apparatus (Jeffery et al., 1989).

\subsubsection{Determination of C/N Ratio of Product Chimato Compost}

$\mathrm{C} / \mathrm{N}$ ratio of each type of product chimato compost was estimated by dividing chimato compost's total carbon by TKN (WSU, 2010) as follows:

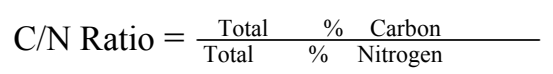

\subsubsection{Determination of $\mathrm{pH}$ of Chimato Compost Samples}

Acidity and basicity, $\mathrm{pH}$, of each type of manure samples was determined using a glass electrode Sargent-Welch digital electronic pH meter (Jeffery et al., 1989).

\subsubsection{Data Analysis}

Test results for TKN, nitrate-N, $\mathrm{C} / \mathrm{N}$ ratios and $\mathrm{pH}$ readings were analyzed using Microsoft excel packages to calculate arithmetic means, standard deviations, graphs and to deduce their relationships to T. diversifolia content in Chimato Compost. Levels of significance of levels of $\mathrm{TKN}$, nitrate-N, $\mathrm{C} / \mathrm{N}$ ratios and $\mathrm{pH}$ in Chimato Composts were statistically determined SPSS 11.5 using Wilcoxon and Mann-Whitney non-parametric tools. Empirical models of the form $\mathrm{Y}=\mathrm{M} 1 \mathrm{X}^{3}+\mathrm{M} 2 \mathrm{X}^{2}-\mathrm{M} 3 \mathrm{X}+\mathrm{C}$; and $\mathrm{y}=\mathrm{MX}+\mathrm{C}$ were developed (where $\mathrm{Y}=$ percentage of $T$. diversifolia and $\mathrm{X}=$ percentage of $\mathrm{TKN}$ or Nitrate-N).

\section{Results and Discussion}

\subsection{Effect of T. diversifolia Content in Chimato Compost Piles on TKN}

Table 2. Effect of $T$. diversifolia content in chimato Compost piles on mean TKN, Nitrate-N, C/N ratio and $\mathrm{pH}$ in chimato Composts

\begin{tabular}{llllllllll}
\hline $\begin{array}{l}\text { Chimato } \\
\text { compost }\end{array}$ & $\begin{array}{l}\mathrm{Td} / \mathrm{MS}^{\mathrm{a}} \\
(\mathrm{V} / \mathrm{V})\end{array}$ & $\begin{array}{l}\mathrm{Td} / \mathrm{MS}^{\mathrm{a}} \\
(\mathrm{w} / \mathrm{w})\end{array}$ & $\begin{array}{l}\text { initial } \\
{\mathrm{C} / \mathrm{N}^{\mathrm{a}}}^{2}\end{array}$ & $\begin{array}{l}\text { Mean } \\
\mathrm{TKN}^{\mathrm{b}} \%\end{array}$ & $\begin{array}{l}\text { Mean } \\
\text { Nitrate-N }\end{array}$ & $\begin{array}{l}\text { Mean } \\
\text { Final } \\
\mathrm{C} / \mathrm{N}^{\mathrm{b}}\end{array}$ & $\begin{array}{l}\mathrm{C}^{\mathrm{b}} \mathrm{N}^{\mathrm{b}} \\
\text { std } \\
\text { Error }\end{array}$ & $\begin{array}{l}\mathrm{Mean}^{\mathrm{b}} \\
\mathrm{pH}^{\mathrm{b}}\end{array}$ & $\begin{array}{l}\mathrm{pH}^{\mathrm{b}} \\
\text { std } \\
\text { error }\end{array}$ \\
\hline Td0 & $0: 100$ & $0: 100$ & $66: 1$ & $1.17 \pm 0.13$ & $0.078 \pm 0.01$ & $38: 1$ & \pm 2 & 7.87 & 0.48 \\
Td20 & $20: 80$ & $24: 76$ & $44 ; 1$ & $1.37 \pm 0.08$ & $0.23 \pm 0.02$ & $27: 1$ & \pm 2 & 8.64 & 0.15 \\
Td25 & $25: 75$ & $39: 61$ & $41: 1$ & $1.55 \pm 0.25$ & $0.48 \pm 0.03$ & $20: 1$ & \pm 1 & 9.26 & 0.25 \\
Td40 & $40: 60$ & $46: 54$ & $32 ; 1$ & $1.67 \pm 0.13$ & $0.82 \pm 0.01$ & $18: 1$ & \pm 1 & 9.47 & 0.25 \\
Td50 & $50: 50$ & $63: 37$ & $28: 1$ & $2.33 \pm 1.11$ & $1.04 \pm 0.03$ & $13: 1$ & \pm 1 & 10.03 & 0.35 \\
Td60 & $60: 40$ & $72: 28$ & $22 ; 1$ & $2.47 \pm 0.11$ & $0.98 \pm 0.02$ & $10: 1$ & \pm 1 & 9.985 & 0.35 \\
Td75 & $75: 25$ & $80: 20$ & $16: 1$ & $2.33 \pm 1.17$ & $0.52 \pm 0.01$ & $17: 1$ & \pm 1 & 9.915 & 0.42 \\
Td80 & $80: 20$ & $89: 11$ & $15: 1$ & $2.02 \pm 0.26$ & $0.57 \pm 0.01$ & $14: 1$ & \pm 1 & 10.04 & 0.42 \\
Td100 & $100: 0$ & $100: 0$ & $11: 1$ & $2.06 \pm 0.21$ & $0.71 \pm 0.02$ & $11: 1$ & \pm 1 & 9.26 & 0.22 \\
\hline
\end{tabular}

\footnotetext{
${ }^{\mathrm{a}}$ in chimato compost pile; ${ }^{\mathrm{b}}$ in chimato composts.
} 
The study results indicated that TKN in chimato Composts $\mathrm{Td} 0, \mathrm{Td} 20$ and $\mathrm{Td} 25$ was significantly different from TKN in chimato Composts Td40, Td50, Td60, Td75 Td80 and Td100, ( $p=0.018) \alpha=0.05$; Wilcoxon). TKN in Td0 was less significantly different from TKN in chimato Composts $\mathrm{Td} 20(\mathrm{p}=0.033)$ and chimato Composts Td25 ( $\mathrm{p}=0.046$ ). TKN in CC Td75 was not significantly different from TKN in chimato Composts Td60 and $\operatorname{Td} 50(\mathrm{p}=0.207$ and $\mathrm{p}=1.000$ respectively, $\alpha=0.05$; Wilcoxon). TKN was very low in $\operatorname{Td} 0$ and increased with increase in T. diversifolia. Increasing T. diversifolia content from $0 \%$ to $60 \%$ in chimato Compost piles increased TKN from $1.17 \%$ to $2.47 \%$ in chimato Composts. The significant differences in TKN content in chimato Composts are attributable to quantities of $T$. diversifolia used in making the corresponding chimato Composts piles because $T d 0$ possessed highest estimated initial $C / N$ ratio $(75 \leq C / N \geq 150: 1)$ due to increased amounts of total carbon atoms in the composite feedstock (Ngeze, 1993; Agromisa, 1990). Thus, Td0 chimato Compost pile possessed least and limited initial TKN which subsequently limited rate of structure building and growth of microbial population, the controlling rate of organic matter decomposition (Onwueme \& Sinha, 1991). Td0 also yielded quantities of TKN, an observation that confirms that percentage of T. diversifolia in chimato Compost piles was responsible for the corresponding TKN increase. In subsequent chimato Composts, successive incremental additions of $T$. diversifolia significantly lowered estimated initial $\mathrm{C} / \mathrm{N}$ ratios (Table 1) of composite feedstock and significantly increased TKN in chimato Composts. Large $\mathrm{C} / \mathrm{N}$ ratio relatively limited TKN content in $\mathrm{Td} 20$ and $\mathrm{Td} 25$ piles resulting in slower microbial activity and lower TKN. The blend relatively contained insufficient amounts of nitrogen for microbes to use in building up their structures (Agromisa, 1990; Darlington, 2010; Ngeze, 1993).

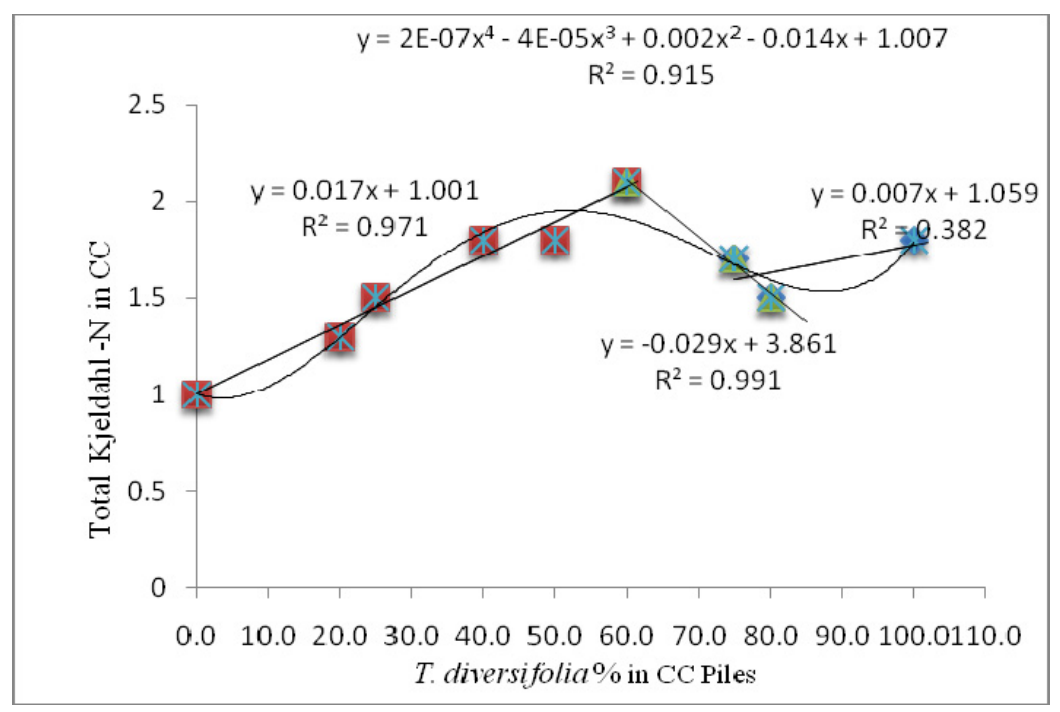

Figure 1. Linear and Curvilinear relationship Effects of T. diversifolia on TKN of chimato Composts

As shown in Figure 1, the graphical relationship showed a strong linear correlation of percentage of $T$. diversifolia in compost piles to TKN in chimato Composts $\left(\mathrm{R}^{2}=0.971\right)$ within the region of $0-60 \%$ of $T$. diversifolia content. This strong linear correlation confirms that percentage of $T$. diversifolia in chimato compost piles significantly influenced the increased TKN content in chimato Composts. The linear relationship is attributed to improved water content, bulk density, and porosity in chimato Compost piles which improved in increasing order of $T$. diversifolia content. The water content and bulk density in chimato Compost piles increased in increasing order of $T$. diversifolia content whereas porosity increased in an increasing order of maize stalks content. Since higher bulk density and higher water content make composite materials more compact, poorly formed and poorly aerated thereby limiting aerobic decomposition (Darlington, 2010; Onwueme \& Sinha, 1991), compost piles experienced limited decomposition in increasing order of T. diversifolia content. Similarly, increasing quantities of maize stalks increased porosity and aeration of composite materials in essence improving porosity and aeration of $T$. diversifolia and thereby enhancing active and rapid aerobic decomposition of piles with greater quantities of maize stalks.

The results also indicated that amounts of TKN were observed declining from $2.47 \%$ in chimato Composts Td60 to $2.33 \%$ and $2.02 \%$ in chimato Composts $\mathrm{Td} 75$ and $\mathrm{Td} 80$ respectively and slightly increased again to $2.20 \%$ in 
Td100. As showed in Figure 1, TKN content indicated a strong negative linear relationship $\left(\mathrm{R}^{2}=0.9918\right)$. The decline is attributed to limited pile porosity, increased bulk density and water content in compost piles (Darlington, 2010; SAEM, 2008). High water content of T. diversifolia (composted while green and fresh) probably increased ingredients density and limited pile porosity which deprived aeration and limited microbial activities and anaerobic decomposition encouraging nitrogen losses as nitrate- $\mathrm{N}$ and ammonia-N. Chimato Composts Td60 registered highest mean TKN of $2.47 \pm 0.10 \%$, whereas Td50 registered second highest mean TKN content of $2.33 \pm 0.11 \%$. Statistically, TKN contents in chimato Composts Td50 and Td60 were not significantly different from each other $(\mathrm{P}=0.201$; Wilcoxon). These findings are attributed to optimum blending ratios of maize stalks and $T$. diversifolia which enhanced optimum porosity, optimum initial nitrogen and optimum low carbon atoms content (Biddlestone \& Gray, 1987; Darlington, 2010; WSU, 2012). The feedstock provided enormous initial nitrogen an optimal initial substrate for microbial activities and optimum carbon atoms content that provided microbes with optimal energy responsible for active and rapid aerobic decomposition.

Further analysis showed that $T$. diversifolia content curvilinearly related to TKN across the range of $0 \%$ to $100 \%$ of $T$. diversifolia of the 4 th degree polynomial $\left(\mathrm{R}^{2}=0.915\right)$ (Figure 1). The correlation confirms that increasing $T$. diversifolia from $0 \%$ to $60 \%$ in the piles cause corresponding increases in TKN quantities in the produced compost from $1.17 \pm 0.13 \%$ to $2.47 \pm 0.10 \%$. Findings further show that subsequent blending with higher percentages of $T$. diversifolia in $\mathrm{Td} 75, \mathrm{Td} 80$ and $\mathrm{Td} 100$ caused $\mathrm{TKN}$ to decline to lower values. However, the TKN values were not significant different from those of Td50 and Td60 ((p>0.289), Wilcoxon). T. diversifolia physico-chemical properties significantly influenced bulk density, porosity and moisture content of compost piles which in turn significantly influenced TKN.

\subsection{Effect of Amounts of T. diversifolia on Nitrate- $N$}

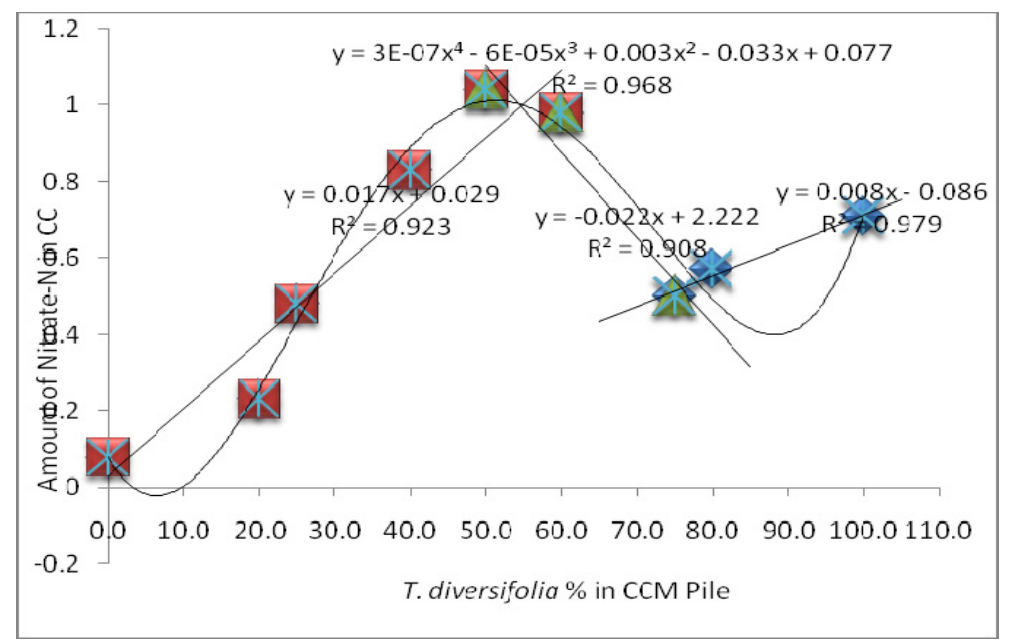

Figure 2. Linear and Curvilinear relationship of T. diversifolia to nitrate-N in chimato Composts

As shown in Figure 2, study results showed that quantity of nitrate- $\mathrm{N}$ in the Td0 (control treatment), was significantly different from Td50, Td60 and Td100 ( $\mathrm{p} \leq 0.008, \alpha=0.01$, Wilcoxon). Nitrate- $\mathrm{N}$ in the control treatment was also significantly different from nitrate- $\mathrm{N}$ in $\operatorname{Td} 40, \operatorname{Td} 75$ and $\operatorname{Td} 80$ ( $\mathrm{p} \leq 0.027, \alpha=0.05$, Wilcoxon). Nitrate-N was very low in Td0 $(0.07 \%)$ and increased from $0.078 \%$ to $1.04 \%$ as quantity of $T$. diversifolia increased from $0 \%$ to $50 \%$. Nitrate-N in Td60 was comparable to and not significantly different from nitrate-N in $\operatorname{Td} 50(\mathrm{p}=0.201, \alpha=0.05)$. Nitrate-N was observed reducing to low levels in chimato Composts whose piles were made using $T$. diversifolia content of greater than $50 \%$. Low nitrate-N $(0.078,0.23$, and 0.48$)$ was observed in $\mathrm{Td} 0, \mathrm{Td} 20$ and $\mathrm{Td} 25$ respectively and high nitrate-N $(0.078,1.04,0.98$, and 0.7$)$ were observed in $\mathrm{T} 40, \mathrm{Td} 50$, $\mathrm{Td} 60$ and Td100 respectively. A high and significant linear regression coefficients $\left(r=0.851 ; \mathrm{r}^{2}=0.923 ; \mathrm{p}=0.006\right.$; $\alpha=0.01$ ) were obtained from the statistical analysis (Figure 2), implying that the controlling mechanism of availability of nitrate-N in the chimato Composts was T. diversifolia content in the chimato Composts piles. Specifically, regression analysis revealed a linear relation between T. diversifolia and Nitrate-N. Nitrate-N in chimato Composts increased from $0.078 \%$ to $1.04 \%$ as T. diversifolia increased from $0 \%$ to $50 \%$. Within this range, successive greater quantities of $T$. diversifolia enhanced greater quantities of nitrate- $\mathrm{N}$ in chimato Composts. Since Td50 possessed greater porosity than Td60 and Td60 possessed greater initial nitrogen 
concentration than $\mathrm{Td} 50$, increased in nitrate- $\mathrm{N}$ is attributable to optimum porosity in $\mathrm{Td} 50$ as well as to larger initial nitrogen concentration in Td60 (Carr, 1998). Optimum porosity initial nitrogen concentration in Td60 and Td50 were well balanced. A 4th degree polynomial relationship showing a high and significant curvilinear regression coefficients $\left(\mathrm{r}=0.937 ; \mathrm{r}^{2}=9686\right)$ of $T$. diversifolia to Nitrate- $\mathrm{N}$ was developed (Figure 2$)$ across the range of $0 \%$ to $100 \%$ of $T$. diversifolia content in chimato Composts. A decline in nitrate-N in Td60 and Td75 and an increase in $\mathrm{Td} 80$ and $\mathrm{Td} 100$ were observed. The inverse linear relationship $\left(\mathrm{R}^{2}=0.9086\right)$ of $T$. diversifolia to nitrate-N (Figure 2) observed in chimato Compost Td60 and Td75 and the increase in nitrate-N in Td80 and Td100 are attributable to physico-chemical characteristics of $T$. diversifolia and maize stalks already described above. T. diversifolia locked up air spaces in the interstices and limited porosity of the chimato Compost pile. This limitation induced greater anaerobic decomposition as evidenced by smell that indicated significant nitrogen emission in the form of ammonia gas $\left(\mathrm{NH}_{3}\right)$ (Onwueme \& Sinha, 1991). Moreover, microorganisms discard excess nitrogen as $\mathrm{NH}_{3}$ during decomposition when nitrogen content exceeded $2.4 \%$ and when estimated initial C/N ratio (Table 1) is less than 12:1 (Biddlestone \& Gray, 1987; Darlington, 2010). Therefore, Ammonia volatilization might significantly influenced $\mathrm{NH}_{3}$ emissions in $\mathrm{Td} 75$, $\mathrm{Td} 80$ and $\mathrm{Td} 100$ and limited nitrate- $\mathrm{N}$ in chimato Compost since nitrogen content exceeded 2.4\% and their C:N ratios were less than 12:1.

3.3 Effect of T. diversifolia Amounts on C/N Ratio of the Chimato Composts, CC

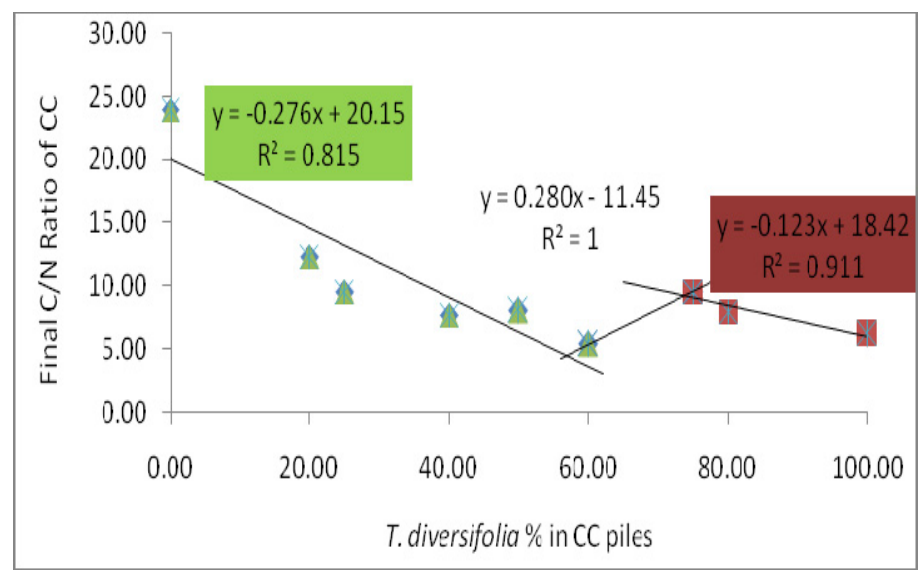

Figure 3. Effect of T. diversifolia on final $\mathrm{C} / \mathrm{N}$ ratios of $\mathrm{CC}$

As shown in Figure 3, results have shown that quantities of $T$. diversifolia in chimato Composts piles decreased initial and final $\mathrm{C} / \mathrm{N}$. Regression analysis revealed an inverse relationship of quantities of $T$. diversifolia and initial $\mathrm{C} / \mathrm{N}$ ratios of composite ingredients. The linear equation showed high negative correlation $\left(\mathrm{R}^{2}=0.9629\right)$ of quantities of $T$. diversifolia and initial and final $\mathrm{C} / \mathrm{N}$ ratios of feedstock confirming that $T$. diversifolia was responsible for the decrease of both initial $\mathrm{C} / \mathrm{N}$ ratios of composite ingredients in chimato Composts piles and final $\mathrm{C} / \mathrm{N}$ ratios of product chimato Composts (Figure 3). T. diversifolia shrubs possess very low $\mathrm{C} / \mathrm{N}$ ratio values (8:1 to 12:1) (Jama et al., 2000) significantly reduced initial $\mathrm{C} / \mathrm{N}$ ratio of the composite ingredients as $T$. diversifolia was successively increased in piles. Blending raised nitrogen content and lowered $\mathrm{C} / \mathrm{N}$ ratio of the composite ingredients (Nalivata, 2007) T. diversifolia, lower $\mathrm{C} / \mathrm{N}$ provided enormous nitrogen for microbes to use in building up their structures that enhanced fast and rapid decomposition and release of nitrogen thereby decreasing the $\mathrm{C} / \mathrm{N}$ ratios further.

The study results also showed that initial $\mathrm{C} / \mathrm{N}$ ratios (66:1, 41:1 and 37:1) of $\mathrm{Td} 0, \mathrm{Td} 20$ and $\mathrm{Td} 25$ (respectively) were too large and outside the preferred optimum range $(25: 1<\mathrm{C}: \mathrm{N}<30: 1)$ to enhance active and rapid decomposition (Biddlestone \& Gray, 1987; Darlington, 2010; WSU, 2005). The high initial C/N ratios can potentially cause nitrogen deficiency in the crop when applied in the field. The high $\mathrm{C} / \mathrm{N}$ ratio of the composite ingredients is attributed to high initial $\mathrm{C} / \mathrm{N}$ ratio of maize stalks that formed the greater percentage of $\mathrm{Td} 0, \mathrm{Td} 20$ and Td25 piles making them to possess excess carbon atoms but limited nitrogen (Ngeze, 1993; Biddlestone \& Gray, 1987; Agromisa, 1990). High final $\mathrm{C} / \mathrm{N}$ ratio of the produced chimato Composts is also attributed to loss of limited nitrogen as ammonia through volatilization because chimato Compost piles $\operatorname{Td} 0, \operatorname{Td} 20$ and $\operatorname{Td} 25$ stayed comparatively longer in the thermophilic phases as discussed in the preceding sections.

As shown in Table 1 , initial $\mathrm{C} / \mathrm{N}$ ratios of chimato Compost $\mathrm{Td} 50$ and $\mathrm{Td} 60$ were within the range of 
200:1 $<\mathrm{C} / \mathrm{N}<30: 1$. Final $\mathrm{C} / \mathrm{N}$ ratios of $\mathrm{CC}$ Td50 and Td60 were 13:1 and 10:1, falling within the desired optimum $\mathrm{C} / \mathrm{N}$ ratio range of 10:1<C/N $<15: 1$ (Nalivata, 2008). The outcome of these final $\mathrm{C} / \mathrm{N}$ ratios falling within the optimum range is attributed optimum initial $\mathrm{C} / \mathrm{N}$ ratios in composite mix/blend which optimized active and rapid decomposition and production of chimato Compost with optimum $\mathrm{C} / \mathrm{N}$ ratios. Therefore, optimum initial $\mathrm{C} / \mathrm{N}$ ratios reduced to recommended final $\mathrm{C} / \mathrm{N}$ ratio in composite ingredients of $\mathrm{Td} 50$ and $\mathrm{Td} 60$ that characterize composts of good quality (WSU, 2010). This observation shows that blending proportions of T. diversifolia and maize stalks in Td50 and Td60 piles were optimal and produced chimato Compost with recommended range of $\mathrm{C} / \mathrm{N}$ ratios. As shown in Table 1 , final $\mathrm{C} / \mathrm{N}$ ratios of $\mathrm{CC} \mathrm{Td} 75, \mathrm{Td} 80$ and $\mathrm{Td} 100$ were significantly different from the $\mathrm{CC} \mathrm{Td} 0, \mathrm{Td} 20$ and $\mathrm{Td} 25(\mathrm{p} \leq 0.028)$. The study results also showed that final $\mathrm{C} / \mathrm{N}$ ratios of chimato Compost $\mathrm{Td} 75, \mathrm{Td} 80$ and $\mathrm{Td} 100$ were not significantly different from initial $\mathrm{C} / \mathrm{N}$ ratios their chimato Compost piles ( $>>0.207$ ). The initial $\mathrm{C} / \mathrm{N}$ ratios were lower than the optimum $\mathrm{C} / \mathrm{N}$ ratio of 25:1 (WSU, 2008; Agromisa, 1990) as well as outside the optimal recommended range of 20:1 to 30:1 (Biddlestone \& Gray, 1987; Ngeze, 1993; Agromisa, 1990) of composting parameters of initial $\mathrm{C} / \mathrm{N}$ ratios. This implied that microbial activities in chimato Compost $\mathrm{Td} 75, \mathrm{Td} 80$ and $\mathrm{Td} 100$ made no significant change in $\mathrm{C} / \mathrm{N}$ ratios. $\mathrm{C} / \mathrm{N}$ ratios of chimato composts $\mathrm{Td} 75$, Td80 and Td100 were observed to be slightly higher $(C / N=17: 1 \quad 14: 1$ and $11: 1)$ than initial $C / N$ ratios $(C / N=16: 1$ 13:1 and 10:1) despite successive reduction of maize stalks that lowered carbon atoms as well as successive addition of $T$. diversifolia that increased nitrogen atoms. The relatively high values of final $\mathrm{C} / \mathrm{N}$ ratios in these chimato Composts is attributed to excessive losses of nitrogen in considerable amounts as ammonia due to reduced porosity, excessive moisture (Biddlestone \& Gray, 1987; Darlington, 2010) and excessive available nitrogen in ingredients. The observed decrease of final $\mathrm{C} / \mathrm{N}$ ratios of chimato Compost made using higher percentage of T. diversifolia (Figure 3) could be attributed to increased amounts of total nitrogen and very low initial C/N ratio of the composite ingredients (Biddlestone \& Gray, 1987). The study results have also shown that final $\mathrm{C} / \mathrm{N}$ ratio of $\mathrm{CC} \operatorname{Td} 75$ (17:1), Td80 (14:1) and Td100 (11:1) were higher than their estimated initial C/N ratio $16: 1,13: 1$ and 10:1 respectively and the later was comparable to final $\mathrm{C} / \mathrm{N}$ ratio of chimato Compost Td60 $(10: 1)$. This agrees to the findings that chimato Compost Td100 possessed enormous nitrogen and experienced greater losses of nitrogen as ammonia as already discussed.

\subsection{Effect of T. diversifolia Amounts on pH of Chimato Compost, CC, Samples}

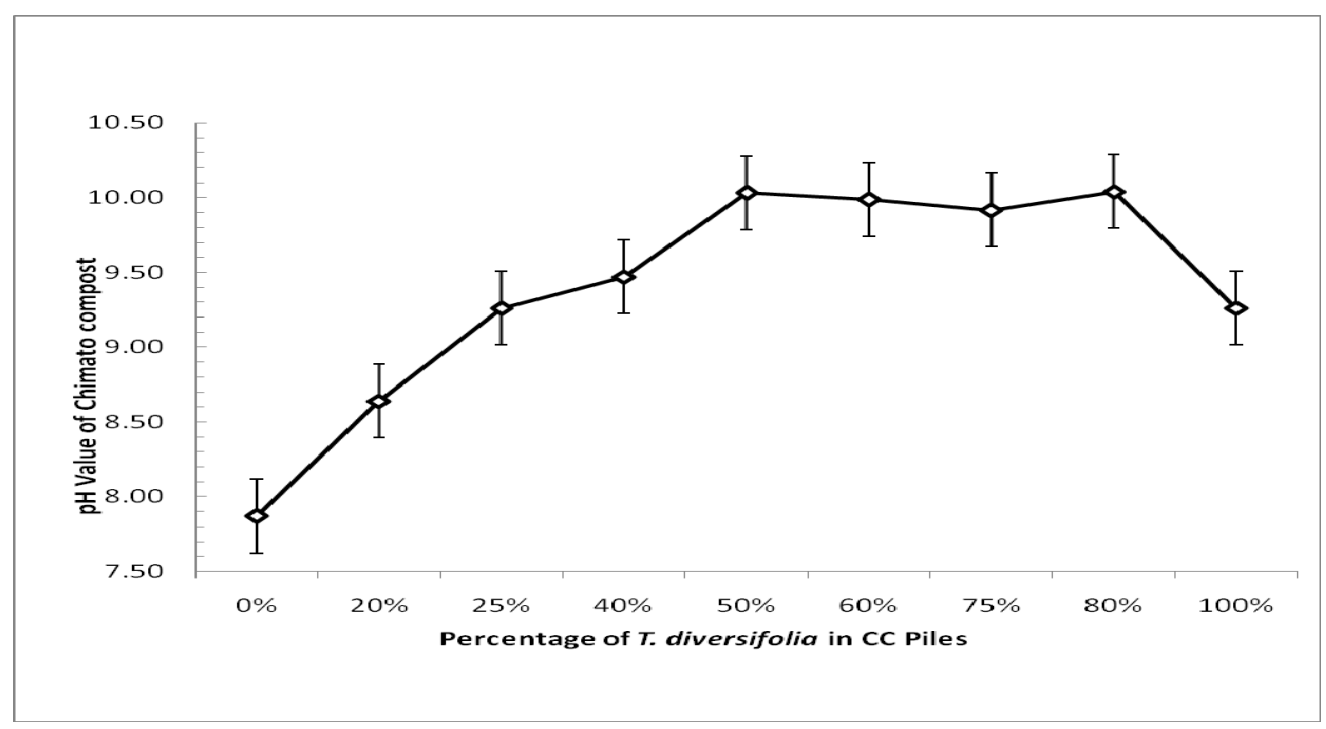

Figure 4. Effect of T. diversifolia on $\mathrm{pH}$ of chimato Compost

As shown in Figure 4, $\mathrm{pH}$ values in chimato Compost increased in increasing order of $T$. diversifolia content as follows: $\operatorname{Td} 0(7.87)<\operatorname{Td} 20(8.64)<\operatorname{Td} 25 \%(9.26)<\operatorname{Td} 40(9.47)<\operatorname{Td} 50(10.03)$. These results show that incremental addition of $T$. diversifolia significantly increased $\mathrm{pH}$ of $\mathrm{CC}(\mathrm{P}=0000$; Wilcoxon $)$ within the range of $0 \%$ to $50 \%$ of $\mathrm{T}$. diversifolia content in chimato Compost piles. $\mathrm{pH}$ values of chimato $\mathrm{Td} 75, \mathrm{Td} 80$ and $\mathrm{Td} 100$ were 9.985, 9.915 and 10.04 respectively. $\mathrm{pH}$ of Td60 indicated no significant difference ( $\mathrm{p}>0.028)$ from those of $\mathrm{Td} 75, \mathrm{Td} 80$ and $\mathrm{Td} 100$. The results showed that $\mathrm{Td} 100$ was relatively more neutral than chimato Compost made 
using lower percentages of maize stalks (lower T. diversifolia). $\mathrm{pH}$ values of $\mathrm{Td} 60, \mathrm{Td} 75, \mathrm{Td} 80$ and $\mathrm{Td} 100$ were higher and more alkaline (Figure 4) than the rest with Td60 being the highest (10.07). Since, composts with high $\mathrm{pH}$ values $(>8.5)$ usually experience significant nitrogen losses by inducing ammonia $\left(\mathrm{NH}_{3}\right)$ vapor volatilization and are also known to cause an inhibition of nitrifying microorganisms (WSU, 2010; WERL, 2005), conversion of nitrogen to nitrates were likely to be inhibited in Td60, Td75, Td80 and Td100. significant ammonia $\left(\mathrm{NH}_{3}\right)$ vapor volatilization subjected to immediate losses are likely to occur in Td60, Td75, Td80 and Td100.

Within the range $0-50 \%$ of $T$. diversifolia content in the chimato Compost pile, $\mathrm{pH}$ was observed to be positively related to nitrate $(\mathrm{r}=0.785)$. Greatest value of nitrate- $\mathrm{N}$ and slightly highest value of $\mathrm{pH}$ value (Figure 4 ) were observed in Td50. Since pH that exceeds about 8.4 is potentially harmful to plants (WERL, 2005) especially maize that grows very in soils with soil $\mathrm{pH}$ of up to 8.0 and never responds in soils with $\mathrm{pH}$ greater than 8.0 (Onwueme \& Sinha, 1991), the pH values would significantly have drastic effects on soil chemistry. However, composts the hydrogen concentration would be heavily diluted when incorporated into the soil thereby reducing the $\mathrm{pH}$ to lower recommended values. Furthermore, high $\mathrm{pH}$ values might have positive implication by buffering plant roots from an unsuitable $\mathrm{pH}$ (acidic) in soil since most theses soils in Malawi and most of other sub Saharan countries have turned acidic due to over reliance on chemical fertilizer application (Onwueme \& Sinha, 1991; WSU, 2010; WERL, 2005). Application of chimato Compost produced using T. diversifolia would serve household farmers with two purposes: 1) raise the $\mathrm{pH}$ of more acid soils to recommended levels and 2) supply nitrogen and other essential plant nutrients to their fields at low cost.

Since $\mathrm{pH}(>8.3)$ values of composts suggest occurrence of $\mathrm{CO}_{3}{ }^{2-}$ precursors to $\mathrm{pH}$, high $\mathrm{pH}$ values could be attributed to presence of $\mathrm{CO}_{3}{ }^{2-}$ such as calcium carbonate or potassium carbonates or sodium carbonate (Onwueme \& Sinha, 1991). Significant amounts of $\mathrm{CO}_{3}{ }^{2-}$ might have been during high degradability of polymeric organic carbon compounds from greater percentage of $T$. diversifolia.

\section{Conclusion}

The study results showed that use of T. diversifolia in making chimato Compost significantly improves TKN, nitrate- $\mathrm{N}$ and $\mathrm{C} / \mathrm{N}$ ratios. Increasing $T$. diversifolia content from $0 \%$ to $60 \%$, TKN and nitrate-N increases from $1.1 \% \mathrm{~N}$ and 0.078 to $2.52 \% \mathrm{~N}$ and $1.04 \%$ respectively while $\mathrm{C} / \mathrm{N}$ ratios decreases from $38: 1$ to $10: 1$ within the same range of $\mathrm{T}$. diversifolia content. The study also identified optimum blending ratios of $T$. diversifolia to maize stalks (50:50 and 60:40) that induced optimum (rapid and active) microbial activities and yielded chimato Compost with optimum TKN (2.52\%), nitrate-N (1.04), and C/N ratios (10:1). Household farmers should be encouraged to make chimato Compost by blending maize stalks with $T$. diversifolia using blending ratios of at least $50 \%$ T. diversifolia that optimizes nitrate-N, TKN, C/N ratios. The chimato Compost made using $T$. diversifolia with such ingredients ratios are more promising in supplying enormous nitrogen to poor soils and reversing soil acidity in acidic soils. However, there is need for further studies to investigate effect of Tithonia diversifolia chimato composts on soil chemistry including the possibility of enhancing underground carbon sequestration and compost pile reduced carbon emissions is also proposed.

\section{Acknowledgement}

I express my profound gratitude to Leadership for Development (Southern and Eastern Africa) (LEAD-SEA) and Malawi Environment Endowment Trust (MEET) for their financial support. I also express gratitude to the Natural Resources College (of Malawi) (NRC) and University of Malawi (UNIMA) for their academic interests in the studies.

\section{References}

Agromisa. (1990). Preparation and use of compost. Agrodox series 8 (pp. 5-10). Wageningen: Agromisa.

American Public Health Association. (1986). Standards methods for the examination of water and wastewater (17th ed.). Washington DC: American Public Health Association (APHA).

Biddlestone, A. J., \& Gray, K. R. (1987). Production of Organic Fertilizers by Composting. In D. J. Moriarty \& R. S. V. Pullin (Eds.), Detritus and Microbial Ecology in aquaculture: ICLARM Conference proceeding (pp. 151-180). Philippines: International Centre for living aquatic resources management.

Chang, C. H., Chen, I. C., \& Yang, S. S. (2009). Methane and Carbon Dioxide Emissions from different composting periods. Terr. Atmos. Ocean. Sci., 20(3), 511-520. http://dx.doi.org/10.3319/TAO.2008.05.20.01(A)

Darlington, W. (2010). Compost- A guide for evaluating and using compost material as Soil amendments. Soil and Plant Laboratory, Inc. 714(282), 8777-8788. 
Department of Agriculture Research Extension and Technical Services (DARETS). (2012). About Chitedze. Lilongwe, Malawi: Department of Agriculture Research Extension and Technical Services.

Eghball, B., \& Power, J. F. (1999). Phosphorus- and nitrogen-based manure and compost applications: corn production and soil phosphorus. Soil Science Society of America Journal, 63(1), 895-901. http://dx.doi.org/10.2136/sssaj1999.634895x

Gachengo, C. N., Palm, C. A., Jama, B., \& Othieno, C. (1999). Tithonia and Senna green (manures and inorganic fertilizers as phosphorus sources for maize in Western Kenya. Agro-forestry Systems, 44(1), 21-36. http://dx.doi.org/10.1023/A:1006123404071

Ganunga, R., Yerokun, O., \& Kumwenda, J. D. T. (1998). Tithonia diversifolia: an organic source of nitrogen and phosphorus for maize in Malawi. In S. R. Waddington (Ed.), Soil fertility research for maize-based farming systems in Malawi and Zimbabwe (pp. 547-567). Google book.

Jama, B., Palm, C. A., Buresh, R. J., Niang, A., Gachengo, C., Nziguheba, G., \& Amadalo, B. (2000). Tithonia diversifolia as a green manure for soil improvement in Western Kenya: A Review. Agro-forestry Systems, 49(1), 201-221. http://dx.doi.org/10.1023/A:1006339025728

Jeffery, G. H., Bassett, J., Mendham, J., \& Denney, R. C. (1989). Vogel's textbook of quantitative chemical analysis (5th ed.). New York: Longman.

Kiptot, E. (2008). Adoption dynamics of Tithonia diversifolia for soil fertility management in pilot villages of western Kenya. Journal of Experiment Agriculture, 4(1), 73-484.

Murugan, A. V., \& Swarnam, T. P. (2013). Nitrogen release pattern from organic manures applied to an acid soil. Journal of Agricultural Science, 5(6), 174-184. http://dx.doi.org/10.5539/jas.v5n6p174

Nalivata, P. C. (2007). Evaluation of factors affecting quality of compost made by smallholder farmers in Malawi. Unpublished doctoral thesis, National Soil Resources Institute, Cranfield University (UK).

Ngeze, P. B. (1993). Artificial fertilizers and how to use them. Nairobi, Kenya: Stantex Publishers.

Njira, K. O. W., Nalivata, P. C., Kanyama-Phiri, G. Y., \& Lowole, M. W. (2012). Biological nitrogen fixation in sole and doubled-up legume cropping systems on the sandy soils of Kasungu, Central Malawi. Journal of Soil Science and Environmental Management, 3(9), 224-230.

Onwueme, I. C., \& Sinha, T. D. (1991). Field crop production in Tropical Africa principles and. Ede, Netherlands: Technical Centre for Agricultural and Rural Co-operation (CTA).

Prochnow, L. I., Kiehl, J. C., Pismel, F. S., \& Corrente, J. E. (1995). Controlling ammonia losses during manure composting with the addition of phosphogypsum and simple superphosphate. Scientia Agricola, 52(2). http://dx.doi.org/10.1590/S0103-90161995000200024

Tanner, M. (2003). Nitrogen in Co-compost and other chemical compost analyses Report of a field study in Kumasi, Ghana. Retrieved from http:// www.bvsde.paho.org/bvsacd/cd48/nitrogen

Washington State University (WSU). (2012). Fundamentals of composting: Why compost, material and methods to ensure quality compost. Whatcom Extension Research Report, Washington State University.

Woods Ends Research Laboratory (WERL). (2005). Interpreting Waste and Compost Tests. Journal of the Woods End Research Laboratory, 2, 1-10.

\section{Copyrights}

Copyright for this article is retained by the author(s), with first publication rights granted to the journal.

This is an open-access article distributed under the terms and conditions of the Creative Commons Attribution license (http://creativecommons.org/licenses/by/3.0/). 